\title{
ensaios de um corpo em estado de experiência: a poética da substância do ato $^{1}$
}

essays of a body in a state of experience: the poetics of the substance of the act

\author{
Adriana Rosa Cruz Santos
}

Universidade Federal Fluminense

\section{RESUMO:}

o presente texto recolhe fragmentos de um percurso de pesquisa de pós-doutorado que toma a errância como dispositivo de abertura do corpo à experiência, ensejando ativar regimes sensíveis e práticas de si-mundo capazes de reencantar o corpo e a vida. A arte de Rosana Paulino e Lygia Clark sopra e ressoa as políticas/poéticas de encantamento e rasga a fina membrana colonial, deflagrando estados de corpo transfigurados pelas intensidades que o interpelam, numa expansão de si que ultrapassa a forma individual e conecta humanos e nãohumanos numa única teia viva, como ensinam os indígenas.

Palavras-chave: regimes sensíveis - colonialidade - corporeidade

\section{ABSTRACT:}

the present text collects fragments of a post-doctoral research path that takes errance as a device for opening the body to experience, giving rise to sensitive regimes and self-world practices capable of reenchanting the body and life. The art of Rosana Paulino and Lygia Clark blow and resonate enchanting policies/poetics and tear the thin colonial membrane, triggering body states transfigured by the intensities that challenge it, in an expansion of itself that goes beyond the individual form and connects humans and non-humans in a single living web, as the indigenous teach.

Key-words: sensitive regimes - coloniality - corporeality

DOI: 10.12957/mnemosine.2020.57647

\footnotetext{
1 “A poética da substância do ato" é uma expressão de Lygia Clark retomada neste ensaio e extraída de "Breviários do corpo" (CLARK, 2019)
} 
...às que me antecederam e às que virão... ${ }^{2}$

\section{tempo zero}

No décimo nono ano do século vinte e um saí para o mundo, vazei do quadro de horários, dos enquadramentos vários, curriculares, modelares, saí, vazei: um ano fora da universidade em pesquisa de pós-doutorado. Mas a universidade não saiu de mim. Sobretudo o macacão-detrabalhadora aderido à pele desde os dezessete anos, quando tirei minha carteira de trabalho, número do PIS e entrei numa sala de aula como professora. No vestido de cetim brocado, conhecida na escola religiosa como a "professora hippinha", lia Bakunin e tinha sérias dúvidas sobre a legitimidade da minha suposta autoridade pedagógica. Tentei ensaiar práticas autogestionárias numa sala com mais de trinta crianças de mais ou menos oito anos. Não deu muito certo, fracasso total. Diagnóstico institucional: "não sabia impor a disciplina". Primeira lição: experiência coletiva não se faz com uma cabeça só. O corpo é talhado desde cedo pra não ser seu, pra ser pertencido por uma voz que manda: a mãe, o pai, a professora, o Estado, a norma, o patrão. E o corpo sobressaltado pela violência que uma sala de aula pode abrigar. Mas isso foi no século vinte.

No século vinte e um, no seu décimo nono ano, saí, depois de muito tempo, da sala de aula. Senti falta, senti saudade do alvoroço bom que os jovens estudantes inauguram no corpo, fazendo me mover por entre páginas, pensadores, acontecimentos, buscando uma preciosidade para lhes apresentar, para multiplicar suas perguntas e manter vivas as minhas, como a agradecer por não pararem de me lembrar que a vida é este movimento incessante, que mal começam e já os encontramos às voltas com seus trabalhos de conclusão de curso, que o ofício de ensinar é indissociável daquele de (des)aprender, que sigo sendo outra, mesmo sendo também aquela que fui.

O que me fez sair-de-ser-professora naquele longínquo 2019 foi um desejo de continuar investigando a ativação de outros regimes sensíveis, sobretudo movida pelas saídas que já vinha

\footnotetext{
${ }^{2}$ Dedico este texto a todas que me antecederam, em especial às minhas bisavós indígenas. marcolina bastos da cruz, cunhatã tirada de seu povo ainda adolescente, viveu 107 anos, cuidou das filhas, carinhou netos, inclusive meu pai, a quem chamava de "periquito". e à minha outra bisa, também "pega no laço", cujo nome se perdeu na poeira, mas sempre foi presença-forte nos modos de cabocla de minha mãe. Bisavós encantadas que me habitam, sopro do vento, força telúrica da mata e do movimento, sinto agora seus passos.

${ }^{3}$ Apesar deste texto ter sido escrito em 2020, o embaralhamento das coordenadas espaço-temporais instaurado pela pandemia do COVID-19 dá uma sensação de habitarmos uma espessura temporal densa e viscosa, como se os dias se sucedessem sem sair do lugar, desfazendo os limiares claros entre ontem, hoje e amanhã. É por este motivo que me refiro a um longínquo 2019, mesmo estando em 2020.
} 
encontrando neste ofício de ensinante, a partir do encontro com Lygia Clark e sua pesquisa com os objetos relacionais ${ }^{4}$. Feitos com materiais variáveis e precários, como sacos plásticos cheios de ar ou água, pequenas almofadas com areia e bolinhas de isopor, pedras, conchas, meias finas e bolas de tênis, os objetos relacionais têm este nome porque ganham consistência no contato com o corpo, são objetos sem forma estável e dotados de alto potencial sensorial. Agenciam, portanto, virtualidades que só se atualizam na relação entre o propositor, o objeto e o corpo do participante, por isso objeto relacional.

Quando colocados sobre o corpo dos participantes e por ali deixados por um tempo, os objetos acionam trânsitos entre os planos extensivo e intensivo, incidindo na dimensão subjetiva. É toda uma microvariação sensorial e subjetiva que é deflagrada, lançando o participante em outros estados de si, capazes de acionar marcas dos acontecimentos vividos, deslocá-las, recompô-las, inaugurando novas experiências de si-mundo. E também mobilizar estados de corpo relacionados aos acontecimentos presentes, traduzindo-os, conectando-os, propiciando-lhes um caminho de expressão e contato.

\footnotetext{
${ }^{4}$ Este encontro se materializou em vários momentos, inicialmente em meados dos anos 1990 em uma parceria com o Projeto "De volta pra casa", coordenado por Gina Ferreira (1996); depois, no início dos anos 2000, no Engenho de Dentro, quando acompanhava a certa distância o trabalho inspirado na Estruturação do Self de Lygia Clark, desenvolvido por Lula Wanderley no Espaço Aberto ao Tempo (WANDERLEY, 1996; 2002) e, finalmente, quando retorno ao Engenho de Dentro em 2014, como pesquisadora, para investigar o trabalho de Lula (SANTOS, 2014) e desdobro esta pesquisa numa outra, que parte do corpo do coletivo de pesquisa como plano de experimentação do corpo-subjetividade no encontro com os objetos relacionais (SANTOS, 2016).
} 


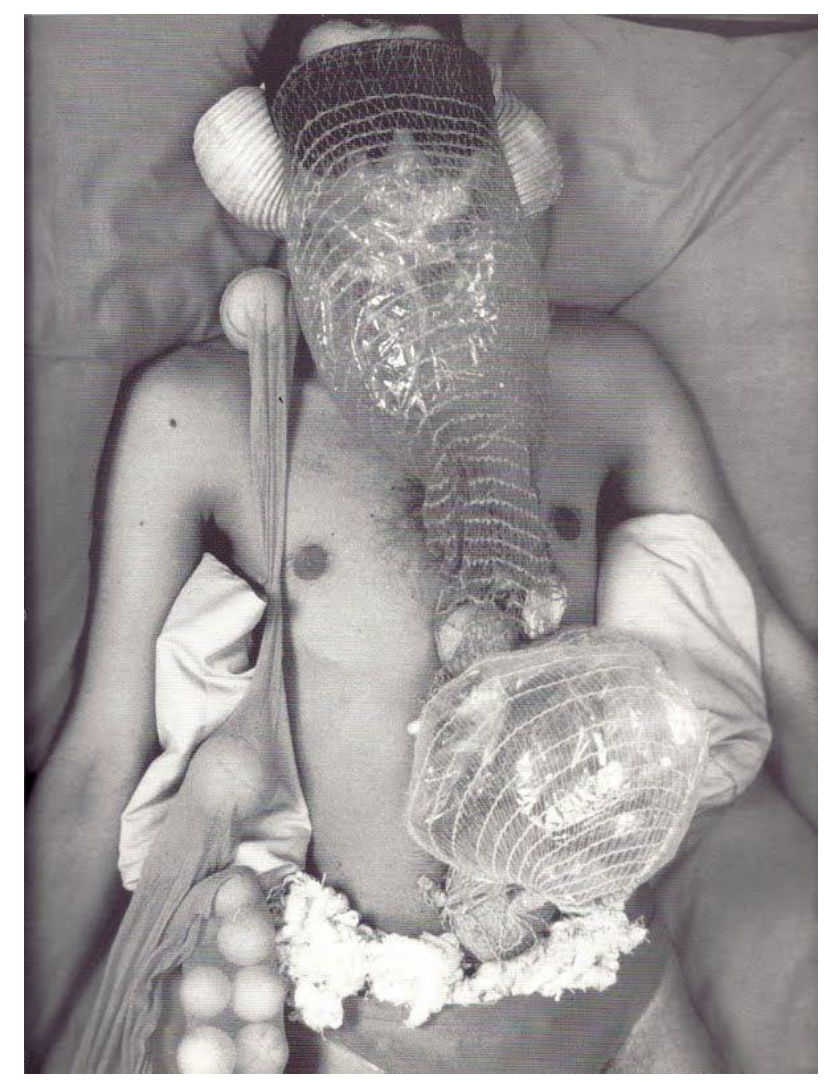

Sessão com os objetos relacionais ${ }^{5}$

Saí temporariamente da docência pra entrar mais intensamente nessa deriva sensorialsubjetiva. O método consistia em me expor ativamente a situações diversas (mas não absolutamente aleatórias) e recolher seus efeitos, suas efetuações, os deslocamentos sensíveis e as variações em meu modo de estar no mundo. Apostar na experiência como processo por meio do qual é possível aprender/apreender/desprender-se-de-si: aprender a ser outra que pesquisa-vive, não só o corpo-cabeça da racionalidade instrumental moderna, ordenador e sobrecodificador, mas o corpo-cabaça, fruto-cuia-maracá, corpo-meio, médium, caboclo, disponível a múltiplos usos e composições; apreender o mundo, ser mundo coextensivamente, ser um modo da substância (SPINOZA, 2007), ser parte singular do plano coletivo imanente que é a vida (COCCIA, 2020); desprender-se da imagem de pensamento (e da encarnadura que 
lhe é correlata), de si como indivíduo encapsulado num psiquismo fechado, meticulosamente separado do plano comum.

Agamben destaca os deslocamentos subjetivos operados na Modernidade e afirma que “[...] o homem contemporâneo foi expropriado da sua experiência" (AGAMBEN, 2008:21) que, domesticada e destituída de sua singularidade disruptiva, passou a existir fora do homem, como ciência. Larrosa Bondía desdobra o argumento de Agamben e afirma que "[...] uma sociedade constituída sob o signo da informação é uma sociedade na qual a experiência é impossível" (BONDIA, 2002: 22). O conhecimento, como sinônimo de informação, impede que a experiência se dê e constitua um saber qualificado. A informação e também a opinião, afirma Larrosa, obstruem a abertura necessária ao desconhecido, ao não-eu. Inibem o estado de receptividade ativa que permite que se viva algo além do estabelecido como verdade, como jádado, como si-mesmo, receptividade que permite a constituição de si-outrem, "território de passagem" (BONDIA, 2002: 22) para o acontecimento.

A experiência é aquilo que se passa em nós quando algo se passa, que desfaz os limites entre si-mundo, aquilo que nos desloca de nós mesmos, fazendo-nos outrxs por meio da relação com outrxs corpos, tangíveis ou não. Um corpo é sempre corpo em relação, um corpo não se define por suas formas ou funções, mas por seus ritmos e por sua potência de afetar e ser afetado, por seus graus de abertura e/ou fechamento a outros corpos, por suas (de)composições (SPINOZA, 2007; DELEUZE, 2002). Todo corpo é um mundo, uma teia de relações que preserva relativa estabilidade entre as inúmeras partes que o compõem, todo corpo é $o$ mundo, pois não possui uma interioridade originária, seu "dentro" se constitui a partir das dobras do "fora".

Heliana Conde Rodrigues não nos deixou esquecer que foi a experiência que impulsionou Foucault em seu percurso de pensamento e vida. O filósofo francês recusava a ideia monumentalizada de livro (e de obra) e delirava o livro como um "objeto-evento" (FOUCAULT, 1989), um convite à experiência de ultrapassagem de nosso tempo, daquilo que nos tornamos, fazendo ver a contingência ali onde só parecia haver necessidade. A experiência, ainda que tenha como suporte material a singularidade somática, o corpo que habitamos/somos, não se limita ao indivíduo ou promove o reencontro com o "sujeito fundador"; antes, age de modo a “[...] 'arrancar o sujeito de si mesmo, fazer com que ele não seja mais ele mesmo', em um empreendimento de 'des-subjetivação"' (RODRIGUES, 2005: 24) 
"Meu problema é o de fazer, e de convidar os outros a fazerem comigo, através de um conteúdo histórico determinado, uma experiência daquilo que nós somos, daquilo que não é apenas nosso passado mas também nosso presente, uma experiência de nossa modernidade da qual saiamos transformados.” (FOUCAULT apud RODRIGUES, 2005: 24-25)

A experiência de des-subjetivação proposta por Foucault pressupõe o desmanche da forma-indivíduo e a germinação de outras possibilidades subjetivas, de modos de existência outros. O recuo à Antiguidade Grega e a proposição de novas relações entre sujeito, verdade e poder por meio de outras estilísticas da existência fazem da experiência o que propicia exercícios de liberdade, não como ideação abstrata e universalizante, mas como efetivo engajamento corporal em outras práticas de si-mundo (FOUCAULT, 2006).

A experiência pressupõe, portanto, um estado mínimo de disponibilidade ao impensável, ao indizível, ao acaso. Pressupõe se deixar tocar pelo acontecimento, abrindo espaços inesperados em si. Encarnar outro corpo, corpo-sem-órgãos (DELEUZE; GUATTARI, 1996), desestratificação do organismo por meio da desfuncionalização dos órgãos e liberação das intensidades.

Assim, inspirada pelo ethos relacional proposto por Lygia Clark e sua aposta na diluição das fronteiras entre artista-objeto de arte-espectador, busquei também escapar às fronteiras entre sujeito-objeto de pesquisa e investigar a arquitetura que me constituía e buscar caminhos que propiciassem a experimentação ${ }^{6}$.

A errância como procedimento. A matéria viva com a qual trabalhei foram os (des)encontros, esbarrões, descobertas, a partir de uma atitude de abertura ativa ao acontecimento, permitindo ser por ele sacolejada, arranhada, diluída, alterada, matada, renascida. Viver como ato de re-criação incessante de si e de mundos, pois como intuiu Lygia Clark, “[...] a vida é sempre[...] o fenômeno mais importante e esse processo quando se faz e aparece é que justifica qualquer ato de criar, pois de há muito a obra para mim cada vez é menos importante e o recriar-se através dela é que é o essencial” (CLARK, 1996: 56). A vida como obra de arte, a pesquisa como a arte experimental da errância.

As errâncias são um tipo de experiência não planejada, desviatória dos espaços urbanos, são usos conflituosos e dissensuais que contrariam ou profanam, como dizo

\footnotetext{
${ }^{6}$ Larrosa (2002) explicita a diferença entre "experiência" e "experimento", sendo este último resultante do aplainamento da primeira pelo pensamento moderno, buscando reduzi-la a uma condição previsível, controlável e universalizável, justamente o oposto do que a noção de experiência encarna. Assim, cabe esclarecer que quando utilizarmos a expressão "experimentar/experimentação" neste texto, referimos-nos a um procedimento de abertura e dessubjetivação, engajando processos singulares e plurais.
} 
próprio Agamben, os usos que foram planejados. A experiência errática, assim pensada como ferramenta, é um exercício de afastamento voluntário do lugar mais familiar e cotidiano, em busca de uma condição de estranhamento, em busca de uma alteridade radical. O errante vai de encontro à alteridade na cidade, ao Outro, aos vários outros, à diferença, aos vários diferentes; ele vê a cidade como um terreno de jogos e de experiências. Além de propor, experimentar e jogar, os errantes buscam também transmitir essas experiências através de suas narrativas errantes. (JACQUES, 2012: 23)

Além do sentido atribuído por Paola Jacques, que conecta mais diretamente a errância à cidade, busco expandir a experiência errática na direção da dimensão intensiva que me interpela, constitui e trans-forma, diluindo as fronteiras dentro-fora, entendendo-a como inapelavelmente experiência na vertical de si mesma ${ }^{7}$ e na tranversal de si-mundo.

Compartilho a seguir, em três tempos, experiências erráticas, ensaios de um corpo em estado de experiência.

\section{tempo um: inventário dos restos ${ }^{8}$}

Alguém falou dos restos, dos rastros, das marcas e vestígios mais que dos resultados e corpos empanturrados de órgãos. Flutuo numa atmosfera de pó em suspensão, atmosfera de muitos lugares: das conferências portuguesas de jojó ${ }^{9}$, passando pelos dedos trêmulos e suaves de Gina ${ }^{10}$ que preparam o mergulho no abismo de bolinhas de isopor ao rodopio de instantes do Seminário da Angel. Do pó vieste, ao pó voltarás, sussurra alguma passagem bíblica. Só me lembro da mulher sem nome e sem rosto virando estátua de sal. A aula de escultura na supervisão em psicologia clínica, aula de vampirismo captada por Luis Antonio Baptista

\footnotetext{
${ }^{7}$ Brinco aqui com a expressão foucaultiana, que interpela e convoca à dessubjetivação, à desestabilização de si mesmo: "filosofia só é uma ética à medida que ela se dá como pensamento da diferença ou ainda, o que dá no mesmo, como pensamento do comum. E, da mesma maneira, a extraordinária coerência do pensamento de Foucault só se dá no risco de si, ou seja, na coragem da problematização contínua de sua própria posição. 'Acreditava afastar-se e se encontra na vertical de si': a coragem e a dignidade do filósofo é essa verticalidade" (REVEL, 2004: 87). É de Michel Foucault a frase entre aspas simples na citação de Judith Revel.

${ }^{8}$ Registro do Diário de campo, setembro de 2019. O relato principal refere-se a uma proposição realizada na abertura do $11^{\circ}$ Seminário Angel Vianna, no Teatro Cacilda Becker, que consistia numa formação de trio, no qual uma das participantes ficaria vendada explorando livremente o espaço (posição ocupada por mim), a segunda deveria cuidar para que a primeira não se machucasse e a terceira participante deveria observar e registrar o exercício.

${ }^{9}$ Referência ao Ciclo de Conferências "Por uma escrita anti-normativa e inventiva: contributos teóricometodológicos de Jacques Derrida, Claude Lévi-Strauss, Julia Kristeva e Roland Barthes”, proferido pelo professor Jorge Ramos do Ó (Universidade de Lisboa), no âmbito do Programa de Pós-graduação de Políticas públicas e formação humana (PPFH/UERJ), em setembro de 2019.

${ }^{10}$ Gina Ferreira, psicóloga, interlocutora e "herdeira" do trabalho de Lygia Clark com os objetos relacionais, com quem tive a oportunidade de fazer a Estruturação do Self, no ano de 2019.
} 
(BAPTISTA, 2001). A memória é feita de fragmentos que se engastam uns nos outros, formando uma colcha colorida que salva do frio e da solidão.

Como listar o intangível, mais ainda, como registrar passagens de estados de corpo? Esta é a tentativa. O procedimento: começo escrevendo a partir do que é suscitado livremente pela memória inscrita no corpo. Depois recorro às anotações e volto a escrever. $\mathrm{O}$ procedimento, como sugerido por Borges em algum conto cujo nome não lembro, é o de escrever muitas vezes a mesma coisa, só que aqui escrevo a cada vez acrescentando uma nova camada, como pintura na parede ou esmalte na unha. Sempre mais uma pincelada modificando as que a antecederam. Memória-canteiro-de-obras. Procedo por acúmulo deliberado dos restos, dos rastros, dos acionamentos intensivos no corpo que (se) escreve enquanto pinta mais uma camada. Nada a desvelar, um vôo (ou um vão) por inventar, uma atmosfera a encarnar. Píndaro pendurado na soleira da porta de Friederich: tornar-se o que se é (NIETZSCHE, 1986).

Comecemos pelo mais perto, pelo que ainda pulsa: tem um coração disparado aqui no peito querendo virar pernas e sair correndo na chuva, se molhar. Acalma coração, me lembra o polaco-samurai malandro: "calma coração/ a confusão prossegue/ sonhos afora/ calma calma / logo mais a gente goza/ perto do osso/ a carne é mais gostosa" (LEMINSKI, 2013). Curitiba, que já foi conhecida pelo seu poeta de bigode nietzschiano, hoje chora chuva cinza de desgosto daquele triste abril que se repete há tantos dias ${ }^{11}$. Perto do osso a carne é mais gostosa. Perto da densidade das fibras, fáscias, febres, fístulas, o corpo é esta presença morna, a vida recobra o ritmo cardíaco, marcando o compasso dos dias.

“Rodopiou como um pião!", exclamou a amiga querida ao me ver girar, girar, girar girar girar... até quase cair. Não tinha essa precisão. A proposta era só andar de olhos vendados com alguém cuidando pra que não me machucasse. Mas não queria facilidades. Lembrei-me da máscara-abismo de Lygia Clark e inventei um procedimento pra perder o equilíbrio e bagunçar o eixo gravitacional que me mantinha sóbria, de pé: virei pião, rodei até ficar tonta e quase cair, reencontrar meu eixo e me perder dos sentidos prévios. Não sabia mais para que lado do palco estava virada e isso me dava uma sensação de liberdade e amplidão. Não saber não doía mais a pressa de um caminho certo, mas se abria inesperadamente como aventura ilimitada. Abri os braços e respirei fundo. Abracei o ar, a vida e as possibilidades a descobrir quando decidi virar

${ }^{11}$ Referência à prisão de Luis Inácio Lula da Silva, ocorrida em abril de 2018, A prisão de Lula foi um desdobramento do golpe deflagrado com o impeachment de Dilma Roussef, em 2016 e possibilitou a eleição de Jair Bolsonaro em novembro de 2018, que nomeou o juiz Sérgio Moro, responsável pela prisão de Lula, como seu ministro da Justiça. Lula ficou 580 dias preso em Curitiba, mesma cidade do poeta Paulo Leminski. 
pião. Ou redemoinho. Virei vento, movimento, poeira levantada pelo desfazimento do contorno estável. O pós-doc era uma liberdade gozosa. Faz pouco tempo ficou assim. Por muito tempo era a liberdade opressiva de quem não sabe virar vento e se assusta com a retirada do macacão de operária, nua, a pele da trabalhadora, a carne docilizada e malhada por tantos anos de escola, de frente ou de costas para o quadro. Neste caso, tanto faz. Corpo embalado na membranaacadêmica, de aspecto brilhante e sedutor e altamente asfixiante. Neste corpo de encarnaduras várias, uma voz silenciara. A poeta ficara no caminho, nos guardanapos, na lembrança dos antigos amigos, só mais um resto.

Mas voltemos ao pião. "roda mundo, roda gigante, roda moinho, roda pião, o tempo rodou num instante nas voltas do meu coração" ${ }^{12}$. Abri os braços, tonta de uma tontura real, decorrente de um movimento "orgânico" e não tonta, como me sentira algumas vezes, por perder o contato "orgânico" com meu próprio corpo e estar nele como uma turista num quarto de hotel, habitando uma intimidade estranha num espaço liso demais, sem marcas, sem rastros. De dentro da tontura real, experimentada a partir das vísceras e não produzida alucinatoriamente pela cabeça, acho meu eixo, um ponto de equilíbrio para me lançar às cegas na exploração. Mas encontro braços macios me embarreirando, braços carinhosos e cuidadores me impedindo. Sinto-me presa, oprimida e tento escapar do controle. Passo a operar reativamente, não sigo mais meu próprio movimento mas deixo-me guiar pelo que se tornou um imperativo: escapar ao controle. O jogo não é gostoso, é cansativo e me perco fazendo movimentos que não eram os que gostaria de fazer. A pessoa que deveria cuidar para que não me machucasse arfa tentando acompanhar meus dribles, percebo o sofrimento em sua respiração. Não faz sentido, desacelero, fico um pouco quieta e busco micromovimentos de liberdade, micromovimentos que não assustem a cuidadora, não acionem seu braço-muro e me permitam, num instante, dar as voltas no meu coração. Aprendo no corpo um jeito de sustentar meu caminho sem me aprisionar na teia reativa, aprendo a transformar o obstáculo num trampolim. O obstáculo é justamente o que me permitiu sair do caminho previsto, o que forçou a encontrar movimentos não-reativos, a inventar outras de mim. Aprendo nessa pequena experiência que é preciso caminhar por desvios, picadas, atalhos, que por grandes estradas pavimentadas, como ensinou o poeta pantaneiro (BARROS, 2010). Aprendo agora com a belezura do corpo, a esperteza da vida que

\footnotetext{
${ }^{12}$ Fragmento da música "Roda Viva" composta por Chico Buarque para a peça de mesmo nome, dirigida por Zé Celso Martinez Correa e encenada durante a ditadura empresarial-militar, em 1968.
} 
vibra no corpo quando não o/a silenciamos. Os olhos estão fechados, mas todos os poros estão abertos.

Inauguro um estado de gratidão: agradeço ao que atrapalha, aprisiona, impede, transtorna, emperra, chateia, irrita. Agradeço ao difícil, ao que arranha, ao que se nega, ao que desafina. Ao que se recusa, ao que desacata, ao que vira parede. Só assim, forçados, no limite do que (achamos que) podemos, encontramos outros jeitos de passar, de sair, de cantar, de correr, de mexer, de respirar. E ao achar outros jeitos, alargando a experiência vital, vou virando outras de mim.

\section{tempo dois: a costura da memória}

Entrei na galeria de paredes brancas, temperatura baixa, falas contidas e circulação suave, em tudo contrastando com o alvoroço barulhento do centro da cidade, de onde vim correndo após saltar do ônibus. Entrei e fui soterrada pelos escombros da subtração na exposição "Rosana Paulino: a costura da memória"13.

\footnotetext{
${ }^{13}$ A exposição "Rosana Paulino: A Costura da Memória" ocorreu no período de abril a agosto de 2019 no Museu de Arte do Rio (MAR), no Rio de Janeiro.
} 


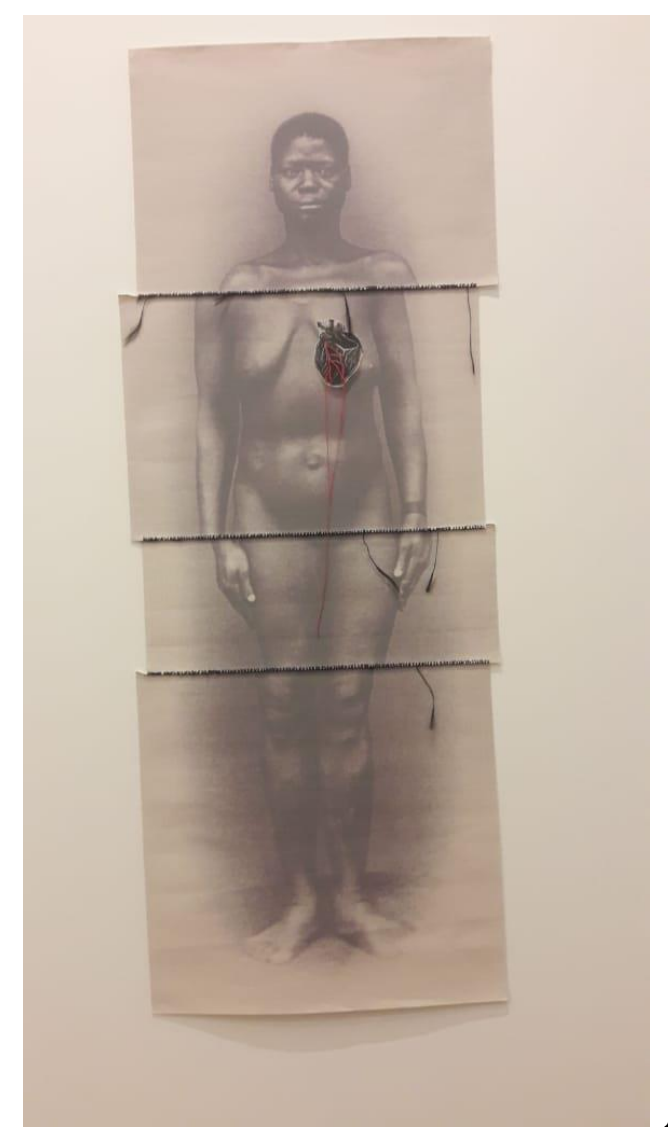

Assentamento, obra de Rosana Paulino, 2013. Acervo pessoal.

Fiquei arrepiada, tremi, chorei. Alguém comenta: "difícil um artista contemporâneo tocar tão forte como a Rosana, os artistas hoje são mais cerebrais, a gente pensa mais que sente quando vê suas obras". Contraste entre as paredes brancas e as esculturas cruas. As obras expostas no museu ensinam mais que muitos ensaios acadêmicos, pois fazem sentir a violência da escravidão, o dilaceramento da mulher negra, a violência branca da ciência incolor. A exposição tem muitas entradas possíveis, fui capturada por uma aranha costureira e fiquei ali, presa na sua teia, re-vendo o mundo do ponto de vista da presa. O corpo preto da mulher raptada do outro lado do atlântico pra virar mercadoria. Pra ser explorada, violentada, exterminada aqui, junto a mulheres, homens e crianças indígenas, gentios a serem convertidos, catequizados, violentamente desaparecidos, "mulheres pegas no laço" pra servirem no banquete patriarcalcolonizador como prova cabal da democracia racial à brasileira. 


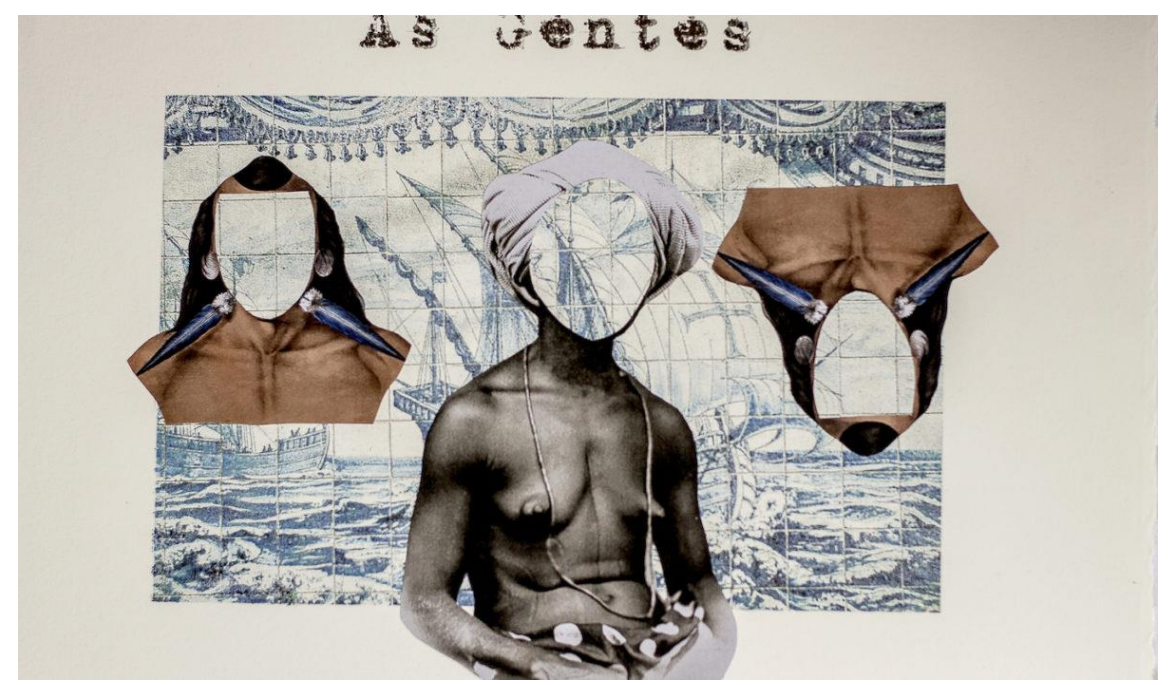

Página de ¿História natural?, obra de Rosana Paulino, 2016. (PAULINO, 2018)

A foto do naturalista branco inaugura a mulher raptada no jardim das espécies, no limiar cego que converte simultaneamente o que é vivo em objeto de estudo para a ciência e mercadoria para o capital. Até hoje. Rosana faz aparecer no corpo dilacerado, vazado pelo olhar científico, um coração de onde escorre, incerto, um fio vermelho de sangue e a sutura-costura incapaz de restaurar a integridade primeira, a integridade que todo corpo tem antes de ser violentado. A costura-sutura emenda como pode, mas tudo permanece ainda fora do eixo. Reencontrar o eixo, mesmo que seja outro, inaugurar um chão pra pisar, se aprumar, andar reconhecendo as próprias pernas, sem desejar outro corpo, outra cor, outra pele. Ouvir as vísceras e sentir se enchendo e esvaziando de ar num ritmo próprio, como a restabelecer a própria presença. Um lugar no mundo, um vazio vivo, pronto pra recomeçar.

Rosana inaugurou em mim um movimento: agarrei o fio vermelho saído do coração e entrei no labirinto de assuntar, sentir e entender melhor os efeitos da colonialidade sobre nossos corpos: diáspora africana, escravização preta, atlântico vermelho, ciência colonial, etnocídio indígena, catequização, extermínio. Comecei na exposição e desde então o labirinto de múltiplos caminhos não saiu mais de mim: fui à Aldeia Marakanã, revisitei a cumbuca familiar e outra bisavó indígena "pega no laço” saiu do armário, “descobri” quase vinte mil indígenas morando no Rio de Janeiro, muitos em favelas e em condições de vida muito difíceis, expulsos de suas terras sagradas por fazendeiros, grileiros, garimpeiros. Olhei pros de perto e os de longe, os de agora e os de anteontem, encontrei fissuras, descontinuidades e longos fios vermelhos 
costurando vidas e trajetórias diversas numa densa e emaranhada teia. Quis revisitar essa história, descobrir outros brasis que me habitam, me encantam, me sustentam.

Procedimento de pesquisa: ficar rebaixada à experiência, em estado propício à mudança de pele, buscando descamar membranas sutis de racionalidade-ocidental-moderna que embala(va)m cuidadosamente as vísceras. Desintoxicação colonial, patriarcal, mental-corporalafetiva, abrindo o corpo a interpelações abortadas pelos muitos anos de subjetivação capitalística (GUATTARI, 1987) e colonial (QUIJANO, 2010). Arrancar a película cuidadosamente sobreposta para dar a ver a cabocla pega à força na mata, arrancada de seu povo e desfigurada de sua sabença pelo sequestro colonial. No esquecimento reiterado e violento de nosso rosto pindorâmico, almejamos ser quem rouba o sopro anímico da terra, a terra que nos sustenta, o sopro que nos mantém de pé. Síndrome de Estocolmo generalizada, “carrego colonial” (SIMAS; RUFINO: 2020), operação de subtração do que somos ${ }^{14}$.

\section{tempo 3: a memória da costura}

Estou deitada no colchão de bolinhas, a cabeça a mil por hora, pensando, pensando, pensando em nada e em muitas coisas ao mesmo tempo. A cabeça resiste, mas o resto do corpo já está entregue, na horizontal, os olhos abraçados por uma almofada pesada e os ouvidos conectados a duas grandes conchas. Assim, suspensos os meios regulares de percepção e apropriação do mundo, desestabilizado o eixo vertical que dá a cabeça a (falsa) impressão de comando sobre todo o resto, o corpo começa a vagar, a se abrir para outras sensações, desestabiliza-se. Movimentam-se também os modos de perceber, de sentir, de pensar, de ser. Variações proprioceptivas. Primeiro um saco de água rola pela perna até pousar no pé. Desconforto inicial, o saco está frio, mas quando chega ao pé, uaaaaauuu, estou no mar e a cabeça finalmente se cala. Outras texturas, pesos, sacos de plástico cheios de ar, pequenas almofadas leve-pesadas, metade areia-metade bolinha de isopor, superfícies irreconhecíveis, sensações de arrepio, aconchego, tecidos finos como pele trazem materialidade às muitas camadas geológicas, afetivas, históricas que sei que sou. Agora sei porque sinto-aprendo-vivo com o toque do voil sobre a pele. Não entendi intelectualmente, conceitualmente, sei com todos

\footnotetext{
${ }^{14}$ Neste ponto me lembro do documentário Ex-pajé, com direção e Roteiro de Luiz Bolognesi, produzido em 2018 pela Buriti Filmes e Gullane e do horror que senti quando o assisti. Reproduzo um fragmento da sinopse: "Até o contato do povo Paiter Suruí com os brancos, em 1969, Perpera era um pajé poderoso. Após chegada dos brancos, um pastor evangélico afirma que pajelança é coisa do diabo e Perpera perde seu papel na tribo, passando a viver com medo dos espíritos da floresta.”
} 
os poros tocados pelo voil que são muitas as camadas que me constituem. Aliás, sinto que sou um plano trespassado por sensações, meu corpo se funde aos objetos e já não sei mais onde começo ou termino. Experiência corpo-sem-órgãos, imersão sensorial, não há mais coordenadas fixas. Flutuo. Ouço o som do pau de chuva e sou lançada pra longe, não tenho mais corpo, sou substância etérea que olha do alto, suspensa no ar, dentro de uma oca indígena. A luz é difusa, sinto a palha como uma membrana que emoldura a cena, sinto os cheiros da terra, da palha, da fumaça e vejo uma sessão de cura: há um corpo deitado no chão, todo recoberto de pequenas penas brancas. O pajé se movimenta numa dança suave, sussurra alguma coisa e dá baforadas com um pequeno cachimbo na superfície do corpo deitado. Depois de um tempo acompanhando aquela cena, sabe-se lá como volto ao colchão de bolinhas, mas ainda não há "eu”. Há um ponto de vista, uma consciência difusa, um ponto flutuante de ancoragem. Sinto-me envolvida pelo som, experimento uma densa presença sonora, estou diluída no som, os sons que ouço no eco produzido pelas conchas no ouvido saem de mim e ocupam todo o ambiente, constituindo uma atmosfera compacta. Não há mais separação eu-ambiente, apenas uma densa ambiência sonora. Sou som. O barulhinho bom das conchas no ouvido vira vento assobiando e sou este som e este ar. Sinto minha coluna como uma flauta, uma brisa a percorrer os vazios, experiência de sons, ocos e ossos. Quando tudo acaba me lembro da "Flauta Vértebra", de Maiakovski (1987). Saio mais vigorosa e inteira da sessão com os objetos relacionais. Meus sentidos parecem mais aguçados, como se tivesse mais viva, mais presente, todo o meu corpo vibra como um animal andando na mata, à espreita, atento aos menores movimentos e sons, estou sutilmente conectada a tudo que me cerca. Olho para o céu, respiro e tudo que vejo deixa de ser a paisagem corriqueira dos dias e se converte numa presença exuberante, um excesso de vitalidade na cidade absorta, o olhar lambe e se lambuza com o sol, o calor e a luz desse dia. Experiência de dessubjetivação, desantropomorfização, desmanchamento de fronteiras, desenho de contornos fluidos. Limiar entre sono e vigília, estado expandido de "consciência", experiência quase onírica. Hoje eu fui o ar que tocou a minha própria flauta-vértebra e a música-vento que dela saía. O self não cabe no eu. ${ }^{15}$

Lygia Clark foi construindo suas proposições a partir do que vivia. "Pedra e ar", que inaugurou a fase sensorial, em 1966, foi criada a partir de um apetrecho plástico que precisou usar para tratar uma fratura no punho (CARNEIRO, 2004). A sagacidade de Lygia de se abrir aos pequenos acontecimentos do cotidiano para deles extrair a matéria para a criação de sua

\footnotetext{
${ }^{15}$ Trecho extraído (e alterado) do Diário de Campo. Relato de sessão de Estruturação do Self, março de 2019.
} 
obra revela um modo de estar na vida que toma a experiência como pista para ensaiar novos percursos estéticos. "[...] Lygia reitera que suas obras tinham pensamento, mas não é uma expressão intelectual.... É uma coisa corporal, sensorial, lúdica, quase perto da natureza, ... é oposto ao intelectual [...] arte sai da barriga e não da cabeça.'” (CARNEIRO, 2004: 98). Noutro trecho da mesma entrevista concedida ao Correio da Manhã, em 1971, ela afirma: “Eu só posso dizer a você que eu sempre fui burríssima. Nunca tive cultura nenhuma, tudo o que eu aprendi, tudo o que hoje eu apresento como reflexões minhas foi consequência do meu trabalho" (CLARK apud CARNEIRO, 2004: 98).

Lygia, como Rosana Paulino, também costurava. Tecia com a própria "baba antropofágica"16 uma densa teia, cujos fios eram a experiência, a memória e o corpo. Aprendia com seu trabalho e seu trabalho era um desdobramento singular de si mesma, circulação, digestão e excreção da experiência. Experiência como ensaio de transfiguração de si, de abertura-fechamento, morte-e-vida; memória como movimento de desobstrução de fluxos entre a forma fixada no corpo e as intensidades a desmanchá-la, buscando caminhos de atualização; corpo como plano intensivo-extensivo de suporte à experiência e de engendramento do gesto e do pensamento.

Com os objetos relacionais Lygia suturava o corpo, preenchia seus buracos, costurava intensidades permitindo-lhes um caminho de expressão. Costura-sutura paradoxal, desatadorade-nós, afrouxando os nexos a fim de restaurar a vitalidade e o movimento de um corpo saturado e intoxicado pelo organismo, esta ordem transcendente e reguladora (DELEUZE; GUATTARI, 1996) diagnosticada por Artaud.

O gesto que deglute o ato na imanência do seu significado. $O$ ato que se supera sem explicações, mãos que se entrelaçam ávidas à procura de um sentido a dois, travessão que liga duas ou mais palavras, corrente que prende a tensão por forte faro, olfato que complementa e perfuma o instante do ato, fruta madura, sem razão aparente no seu existir, que não se pergunta, que se exprime só no seu existir. O aproximar-se sem o compromisso do tempo, sem data, sem o conceito do futuro, onde prevalece a sabedoria do estar-sendo. O precário que dignifica o presente, que rompe com o conceito da continuidade. O ponto da tapeçaria que procura o parceiro no fio mais próximo, na escala de uma continuidade vinda da origem, a escolha sem regras, o jogo que se abre diante de dois parceiros, cúmplices diretos da mesma regra, não no sentido competitivo mas no da complementação do seu significado. A alegria do descobrimento do momento percebido, vivido na imanência da comunicação tão primitiva quanto primária, tão autêntica quanto viva, trazendo em si um sentido nunca

\footnotetext{
${ }^{16}$ Baba Antropofágica é uma proposição de 1973 em que um participante se coloca deitado, rodeado pelos demais participantes que têm na boca um carretel, de onde vão puxando uma linha com a qual recobrem o corpo do participante deitado. Lygia se inspirou em um sonho que teve para criar esta proposição.
} 
antes percebido, dois seres surdos e mudos, num mundo da dialética contraditória. A poética da substância do ato, limpa de toda a representação da linguagem. $O$ aproximar-se, o afastar-se, o reaproximar-se na medida do desejo, o fluxo e refluxo do mar que cobre a areia, subterrâneo da origem celular [...] (CLARK, 2019:122)

"A poética da substância do ato, limpa de toda representação da linguagem" inaugura um sentido de experiência ainda mais sutil que os propostos por Agamben, Larrosa Bondía e Foucault. Incorpora e expande os sentidos anteriores no plano intangível das micropercepções, das sensações-sem-nome, das intensidades a-significantes. $\mathrm{O}$ ato limpo de toda sobrecodificação, como puro acontecimento, sem sujeito, sem intenção, sem consciência.

Há platôs de experiência que se comunicam transversalmente, de acordo com o grau de abertura propiciado pelo acontecimento e sua potência de acessar camadas mais ou menos sutis. A experiência de entrar em contato com a obra de Rosana Paulino revirou minhas entranhas de modo diferente como fui revirada pela experiência em que tive que me movimentar vendada e amparada e pelas sessões com os objetos relacionais. Os objetos possibilitaram que eu acessasse uma camada mais sutil, num processo bonito de afrouxamento do limiar da consciência e de emergência de outro plano que me habita, informe e fortemente germinativo, rearticulador de marcas de memória, capaz de acionar virtualidades, na fabricação fluida de novas marcas. Este processo ampliou o meu tônus experimental, o grau de abertura e receptividade ativa aos (micro)acontecimentos, me fez aprender mais de mim e do mundo, apreender o continuum simundo, fazendo desabar o feitiço antropocêntrico colonizador, de um humano hierarquicamente superior e apartado do que fora outrora designado como "natureza".

Ter nascido significa isto: não ser puro, não ser si mesmo, ter em si alguma coisa que vem de outro lugar, alguma coisa de estranho que nos leva a cada vez nos tornarmos estrangeiros a nós mesmos. Nós carregamos em nós mesmos nossos pais, nossos avós, os pais deles, os macacos pré-humanos, os peixes, as bactérias, até os mínimos átomos de carbono, hidrogênio, oxigênio, azoto etc. Nunca seremos homogêneos, transparentes, perfeitamente reconhecíveis. A metamorfose não é simplesmente a sucessão de duas diferenças, ela é a impossibilidade de substituir a outra, a coexistência paradoxal dos possíveis mais afastados em uma única e mesma vida. (COCCIA, 2020: 53)

Incluir a coexistência paradoxal de dimensões assimétricas numa única e mesma vida é o que fazem há milênios os povos originários de Abya Yala, "Terra Madura", "Terra Viva" ou “Terra em florescimento", expressão do povo Kuna, da Colômbia, utilizada para designar a 
América. ${ }^{17}$ E também os povos originários de outros tantos lugares, inclusive da própria Europa, antes de ser colonizada pelo capitalismo e exterminar mulheres consideradas bruxas por utilizar ervas, se relacionar com as forças da natureza ou constituírem redes femininas de autocuidado (FEDERICI, 2017).

A ancestralidade dos povos originários se conecta à ancestralidade cosmológica dos viventes do planeta Terra indicada por Coccia, que se conecta à ancestralidade poética e intuitiva de Lygia Clark, que se conecta à ancestralidade contemporânea de Rosana Paulino, numa ciranda aberta a outras tantas conexões. O encantamento, pensamento e modo de viver que inclui a dimensão imaterial e ancestral da existência é o que vem sendo apagado pela colonialidade. Com Simas e Rufino afirmamos o encantamento como importante linha que costura aquilo que somos/podemos ser, como nos movemos no mundo, como somos-mundo. $\mathrm{O}$ encantamento deflagra um ethos dessubjetivante e aciona regimes sensíveis capazes de deslocar a forma individual-capitalística, assentando nossa existência no plano coletivo e cósmico.

A noção de encantamento traz para nós o princípio da integ ração entre todas as formas que habitam a biosfera, a integração entre o visivel e o invisivel (materialidade e espiritualidade) $e$ a conexão e relação responsivalresponsável entre diferentes espaços-tempos (ancestralidade). Dessa maneira, o encantado e a prática do encantamento nada mais são que uma inscrição que comunga desses princípios. Para nós, é muito importante tratar a problemática colonial na interlocução com essa orientação. Entendemos que a matriz colonial é uma das chaves para pensarmos a guerra de dominação que se instaura entre mundos diferentes. (SIMAS; RUFINO, 2020: 7)

Larrosa Bondía (2002) já havia alertado que numa civilização onde predomina a informação e a opinião não há espaço para a experiência. Retomamos esta assertiva para acrescentar que onde há colonialidade, onde há sobrecodificação significante do vivido, onde prevalece a vida asfixiada pelo imperativo asséptico da utilidade, produtividade e segurança, vida reduzida ao consumo de objetos, estilos de vida e corpos considerados descartáveis, há muito pouco espaço para a experiência.

Estamos, portanto, como alertaram Simas e Rufino, em meio a uma guerra entre diferentes mundos, entre distintas cosmopolíticas e políticas de subjetivação. Não há paz neste

\footnotetext{
17 “Abya Yala vem sendo usado como uma autodesignação dos povos originários do continente como contraponto a América. A expressão foi usada pela primeira vez em 1507, mas só se consagra a partir do final do século XVIII e início do século XIX, por meio das elites crioulas, para se afirmarem no processo de independência, em contraponto aos conquistadores europeus. Muito embora os diferentes povos originários que habitam o continente atribuíssem nomes próprios às regiões que ocupavam - Tawantinsuyu, Anahuac, Pindorama -, a expressão Abya Yala vem sendo cada vez mais usada pelos povos originários do continente objetivando construir um sentimento de unidade e pertencimento.” Texto extraído de https://iela.ufsc.br/povos-origin\%C3\%A1rios/abya-yala.
} 
mundo que não seja violenta, que não tenha implicado ao longo dos últimos séculos o silenciamento e a morte de tantos. Restituir o corpo como plano de emergência e inscrição de regimes sensíveis encantados e como condição para a experiência e para a constituição de um saber contracolonial é, portanto, um grito, uma luta, uma manhã, um amanhã.

\section{tempo zero: suspendendo o céu}

Os saberes originários e ancestrais, a arte, o pensamento encarnado no corpo, a aposta no continuum da vida, a teimosia coletiva, o amor como prática política de abertura à diferença, a poesia como delírio da palavra e o que mais conseguirmos encontrar e inventar são todas armas imprescindíveis nestes ensaios de viver entre muitxs. Apenas encantando nossos corpos, abrindo-os à experimentação, à metamorfose, aos ciclos incessantes de transformação, numa conexão imanente e transversal com as diferentes dimensões da vida neste planeta será possível combater a morte que nos ronda desde sempre, o desencantamento colonial. "Considerando que viver é artimanha que se cultiva entre aquilo que se enxerga e aquilo que mora no invisível, seguimos o rastro da flecha que atravessa o tempo: o contrário da vida não é a morte, o contrário da vida é o desencanto.” (SIMAS; RUFINO, 2020: 10)

Este texto integra o dossiê de um evento que aconteceu entre outubro e novembro de 2019 e foi feito por muitas mãos, vozes e sopros. Nossa aposta de encantamento é plural e se interessa pelas políticas de subjetivação e pelos regimes sensíveis que lhes são imanentes. A política e a poética.

Habitamos hoje o limiar entre um tempo que não passou e outro que não sabemos quando chegará. Termino esta frase em dezembro de 2020, após nove meses de isolamento social, quando a pandemia do COVID-19 já matou 182 mil pessoas no Brasil, numa semana em que mais dois jovens pretos foram assassinados pela Polícia ${ }^{18}$, indígenas munduruku da Terra Sawré Muybu ${ }^{19}$ apresentaram níveis inseguros de mercúrio em seus corpos, em decorrência do garimpo ilegal e as cigarras, que ignoram nossas humanas violências, cantam lindamente na minha janela, anunciando que o verão está chegando, mais uma vez. Termino aqui com os olhos

\footnotetext{
18 Matéria completa em: https://www1.folha.uol.com.br/cotidiano/2020/12/policiais-sao-filmados-atirando-emjovens-negros-em-moto-no-rj.shtml

${ }^{19}$ Pesquisa da Fiocruz revela contaminação por mercúrio entre os Munduruku em decorrência do garimpo ilegal. Reportagem completa em: https://g1.globo.com/jornal-nacional/noticia/2020/12/07/pesquisa-da-fiocruz-revelacontaminacao-por-mercurio-em-terra-indigena-do-para.ghtml
} 
ardendo após um semestre de aula e tudo-o-mais remoto e do choro que tem vazado, regularmente e aos bocados, buscando passagem para uma dor que não é só minha.

\begin{abstract}
Alguns povos têm um entendimento de que nossos corpos estão relacionados com tudo que é vida, que os ciclos da Terra são também os ciclos dos nossos corpos. Observamos a terra, o céu e sentimos que não estamos dissociados dos outros seres. O meu povo, assim como outros parentes, tem essa tradição de suspender o céu. Quando ele fica muito perto da terra, há um tipo de humanidade, que por suas experiências culturais, sente essa pressão. [...] aqui nos trópicos essa proximidade se dá na entrada da primavera. Então é preciso dançar e cantar para suspendê-lo, para que as mudanças referentes à saúde da Terra e de todos os seres aconteçam nessa passagem. [...] Suspender o céu é ampliar os horizontes de todos, não só dos humanos. [...] Quando pensamos num tempo além deste, estamos sonhando com um mundo onde nós, humanos, teremos que estar reconfigurados para podermos circular. Vamos ter que produzir outros corpos, outros afetos, sonhar outros sonhos pra sermos acolhidos por esse mundo e nele podermos habitar. Se encararmos as coisas dessa forma, isso que estamos vivendo hoje não será apenas uma crise, mas uma esperança fantástica, promissora." (KRENAK, 2020: 46-47)
\end{abstract}

“É preciso cantar e dançar para suspender o céu”. Recobrar a alegria como força de encantamento e luta. "Vamos ter que produzir outros corpos, outros afetos, sonhar outros sonhos [...]" Vamos precisar construir outros modos de viver, com curiosidade pelo mundo, encantamento e diálogos de mãos. Experimentar outra ordem de contágios. "Encarnar a poética da substância do ato”. E nunca mais esquecer: estamos vivos, agora.

\title{
Referências
}

AGAMBEN, Giorgio. Infância e história: destruição da experiência e origem da história. Belo Horizonte: Editora UFMG, 2008.

BAPTISTA, Luis Antonio. A fábrica de interiores: a formação psi em questão. Niterói: EdUFF, 2001.

BARROS, Manoel de. Poesia Completa. São Paulo: Leya, 2010.

BONDIA, Jorge Larrosa. Notas sobre a experiência e o saber de experiência. Rev. Bras. Educ. [online]. 2002, n.19, pp.20-28. ISSN 1413-2478. https://doi.org/10.1590/S141324782002000100003

CARNEIRO, B. S. Relâmpagos com claror: Lygia Clark e Hélio Oiticica, vida como arte. São Paulo: Imaginário/FAPESP, 2004.

CLARK, Lygia. Lygia Clark - Hélio Oiticica: cartas, 1964-74. Organizado por Luciano Figueiredo. Rio de Janeiro: Editora da UFRJ, 1996.

CLARK, Lygia. Breviário sobre o corpo. Concinittas. Revista do Instituto de Artes Plásticas da $\begin{array}{llllll}\text { UERJ. } & \text { v. } & 1, & \text { n. } & 26 & \text { (2015). }\end{array}$ publicacoes.uerj.br/index.php/concinnitas/article/view/20119

COCCIA, Emanuelle. Metamorfoses. Rio de Janeiro: Dantes, 2020. 
DELEUZE, G.; GUATTARI, F. 28 de novembro de 1947 - Como criar para si um corpo sem órgãos. In: 34, 1996. . Mil platôs - capitalismo e esquizofrenia, vol. 3. Rio de Janeiro: Ed.

DELEUZE, Gilles. Espinosa: filosofia prática. São Paulo: Escuta, 2002.

FEDERICI, S. Calibã e a bruxa: mulheres, corpo e acumulação primitiva. São Paulo: Elefante, 2017.

FERREIRA, Gina. De Volta para casa. In: PITTA, A. (org.) Reabilitação psicossocial no Brasil. São Paulo: HUCITEC, 1996.

FOUCAULT, M. História da loucura na idade clássica. São Paulo: Ed. Perspectiva, 1989.

FOUCAULT, M. A ética do cuidado de si como prática da liberdade. In: FOUCAULT, M. Ética, sexualidade, política. Rio de Janeiro: Forense Universitária, 2006.

GUATTARI, F. Revolução Molecular: pulsações políticas do desejo. São Paulo: Brasiliense, 1987.

KRENAK, AILTON. A vida não é útil. São Paulo: Companhia das Letras, 2020.

JACQUES, Paola Berenstein. Elogio aos errantes. Salvador: EdUFBA, 2012.

LEMINSKI, Paulo. Toda poesia. São Paulo: Companhia das Letras, 2015.

MAIAKÓVSKI, V. Antologia poética. São Paulo: Max Limonad, 1987.

NIETZSCHE, Friedrich. Ecce Homo: como alguém se torna o que se é. São Paulo: Max Limonad, 1986.

PAULINO, Rosana. Catálogo da Exposição Rosana Paulino: a costura da memória / curadoria Valéria Piccoli, Pedro Nery ; textos de Juliana Ribeiro da Silva Bevilacqua, Fabiana Lopes, Adriana Dolci Palma. São Paulo: Pinacoteca de São Paulo, 2018.

QUIJANO, Anibal. Colonialidade do poder e classificação social. In: SANTOS, Boaventura de S.; MENESES, Maria Paula (orgs.). Epistemologias do sul. São Paulo: Cortez, 2010.

REVEL, Judith. O pensamento vertical: uma ética da problematização. In: GROS, Frédéric et alii (orgs). Foucault: a coragem da verdade. São Paulo: Parábola, 2004.

RODRIGUES, Heliana de Barros Conde. Desencaminhando o presente 'psi'. Biografia, experiência e temporalidade em Michel Foucault. In: GUARESCHI, N. ; HUNNING, S. (Orgs.) Foucault e a Psicologia. Porto Alegre: ABRAPSO Sul, 2005.

SANTOS, Adriana Rosa C. Projeto de pesquisa "Engenhos do fora: objetos relacionais, arte e loucura". Instituto de Psicologia. Universidade Federal Fluminense. Niterói, 2014.

SANTOS, Adriana Rosa C. Projeto de pesquisa "Memória da pele, membrana da alma: corpo, pensamento e subjetividade". Instituto de Psicologia. Universidade Federal Fluminense. Niterói, 2017.

SIMAS, Luiz Antonio; RUFINO, Luiz. Encantamento: sobre política de vida. Rio de Janeiro: Mórula Editoria, 2020. Disponível em: 〈https://morula.com.br/produto/encantamentosobre-politica-de-vida/>

SPINOZA, Baruch. Ética. (trad. Tomaz Tadeu). Belo Horizonte: Autêntica Editora, 2007. 
WANDERLEY, Lula. O vazio vivo. In: PITTA, A. (org.) Reabilitação psicossocial no Brasil. São Paulo: HUCITEC, 1996.

WANDERLEY, Lula. O dragão pousou no espaço: arte contemporânea, sofrimento psíquico e o objeto relacional de Lygia Clark. Rio de Janeiro: Rocco, 2002.

Adriana Rosa Cruz Santos Universidade Federal Fluminense E-mail: adrianarosa@id.uff.br 